\title{
Preparation of the Specialists in the Sphere of Economic Security
}

\author{
Galina Zlotnikova \\ Financial University under the Government of the Russian Federation \\ Moscow, Russia \\ E-mail: gkz06@mail.ru
}

\begin{abstract}
The paper puts the problems associated with the preparation of the specialists in the sphere of economic security, the introduction of risk minimization system built on the basis of the characteristics of the activities and the functioning branch of the economic entity, and the relevance of the risk classification for the development of an effective risk minimization system. As the solution, it is proposed to bring in professional economic security staff into the activities of small business.
\end{abstract}

Keywords-economic security specialist; risks of economic entities; risk minimization system; internal control

\section{INTRODUCTION}

Issues related to the Russia's national security protection are directly linked to the need to comply with the conditions of sustained and stable development of small business, which is, due to the experience of developed countries, the basis of the country's economy. It is paid almost no attention in enterprises to the economic component of the concept of "economic security".[4] To ensure the security of the economy and its development, the concern of training of specialists in this area is raised, and this problem has attracted the attention of scientists, experts and businessmen. Existing large-scale economic threats and real economic damage, which arecaused to the country and the business due to the lack of sophisticated assessment and management economic security system, put this problem on one of the first places in the economic life of the country.Economic security threats are events and processes that adversely affect the country's economy, impede the realization of economic interests of the individual, society and state, pose a danger to national values and destabilize the socio-economic position in society. [3]

And in this situation the training of professional personnel for the economic security stands in the first place in the process of realization of this idea.

\section{OBJECTIVES AND METHODS}

At present, new approaches are required to reform the economy, manage enterprises in various industries and generate economic policies and strategies that would allow small businesses to maintain a competitive advantage in the short and long run and feel the real support from the state.
Effective economic subject governance solutions are impossible without a scientific elaborated theory based on practical experience and advanced training of professional staff, which is able to analyze the situation, predict outcomes and make effective decisions.

Today, the urgency in a partnership between higher education and business institutions necessitates a new modern innovative approach to the preparation of modern specialists, which should create a framework for the national economic system efficiency improvement, i.e. to ensure the Russia's national security.

Let's emphasize the need and importance of the educational process methods, educational technology and improvement, including e-learning, distance learning technologies, which significantly would help to enhance the learning motivation of students in the framework of training, judgment, thinking, personal enrichment and general knowledge of the future professional.

The state's role in this issue is important because a professional innovative learning requires investments in science, technology and financial resources.

Economic security as a science is a system of integrated approach to ensure a stable, sustainable, effective use of industrial, financial and other resources of the economic entity. This system increases the performance growth of the economic entity, of the production and the economy in general, as well as is based on special knowledge of professional staff about the company's development and functioning laws, directly related to the:

- analysis of economic processes which take place in the economic entity;

- scientific analytical justification of business plans,

- approval of professionally competent management decisions, their assessment and forecasting;

- identification and expert analysis of the possible positive and negative factors using quantitative measurements of thresholds for each center of responsibility;

- identification of internal reserves that affect the increase of production efficiency; 
- development of the risk minimization system on the basis of their forecasting and analysis, the specifics of the economic entity, the influence of the country, financial and production features;

- holding of the ongoing independent monitoring, prevention and prediction of potential risks;

- finding of the vulnerabilities in the security system of the economy;

- prevention of internal and external threats to the security of the economy and business in general;

- development of a quality risk management system, etc.

\section{RESULTS AND DISCUSSION}

\section{A. Preparation of Professional Staff in the Economic Security System}

According to the L.I. Abalkina's judgment, "the economic security is a state of the economic system, which allows it to develop rapidly and efficiently and to solve social problems and in which the state has the ability to develop and implement an independent economic policy" [2].

In practice, issues related to the economic security are necessary to be solved by the economic security staff of almost any organization, and this, in turn, sets the educational institutions the specific tasks for the preparation of professionals who are able to:

- accomplish the construction of the economic subjectrisk management integrated system, in other wordsprovide a comprehensive approach to the economic security of business;

- build a comprehensive organization's risk assessment and prediction system;

- create an effective system of internal control and audit on the basis of implementation of the operative controlling system as an effective tool for the functioning of the economic system of security in the company;

- develop a system of decision-making on the basis of the risk flag of a particular economic object, on the assumption of the characteristics of the industry.

Currently, the question of the training of specialists to ensure the entity economic security has come up quite sharply, which are able to professionally and effectively create a system to minimize risks, to confront fraud and corruption risks, to increase the level of competitiveness and economic stability of a particular organization.

With the unstable economic growth and realignment of various companies in the market, the professional requirements for potential employees from the perspective of employers' positions are increasing, and higher education institutions, unfortunately, cannot provide the required amount of quality economic security professionals. Modern criminals, especially in financial and economic sphere, build their fraudulent, criminal and corruption schemes with the help of modern business tools, and not every specialist will be able to make out the features in elementary fraudulent transactions and schemes.

The problem of economic security in the enterprise and government agencies is a fashionable trend today. The more the stability and efficiency of Russian economy develop, the more likely there are positive developments in the field of training of specialists in this sphere. Today, "security is a state of defending the vital interests of the individual, society and state from internal and external threats". [6]

Students which graduate from Russian universities are often detached from reality, not to mention the quality of the acquired education. The amount of the educational institutions which are capable to prepare high quality professionals in the field of economic security is not enough. The demand for these human resources determines the economic situation at the moment. The variability of the microenvironment, new remedies of the crisis, the launch of the process control and protection are the knowledge that is obtained experimentally. Many experts which are recognized as established risk analysts have first, basic education which is legal, economic, less frequently technical and on this basis, as a rule, in self - practice - oriented way, study the safety mechanism of the economy in order to acquire the missing knowledge.

\section{B. Features of the Structure and the Education of "Economic Security" Program}

Thus the question arises about the need to move away from the standard circuits of the "Economic security" programand to introduce a certain balance of theory and practiceinto it, which will provide high-quality, practical value of specialists in this field.

S. and A. Lykshin Swinarenko noted that the market economy (especially in a country such as Russia) is unthinkable without the elements of centralized management. Where it is reasonable, it is necessary to actively introduce methods of state planning and management of the country's economic life. [5]

Theoretical and scientific methodological development, which forms a unified perception of the economic entity security as an important component of the modern economy, allows to study, compile and disseminate the accumulated experience of ensuring the economic security of small businesses and to transfer it into working curricula of higher education institutions which educate these academic programs.

Currently, there are scientific developments of economic safety standards in the various educational institutions, which are important for those who have faced problem of the economic security ensurance. These studies serve as systemic guidelines - the methodology of software, methods and techniques for carrying out economic security research is developedand it is the basis for the training of specialists analysts with professional judgment in this area. The 
economic security threat to the organization is a combination of factors and impact of external and internal environment of the enterprise which are aimed at illegal or willful obstruction or difficulty of its functioning in accordance with the charter, long-term and short-term goals and objectives, as well as at the alienation of the results of its activity [1].

During the education process, the student should receive theoretical training in his chosen specialty and develop practical skills that should be based on the following knowledge:

- theoretical methodological foundations and understanding and the possibility of creating economic security concept of the economic entity;

- methodological research in the area of economic security and its maintenance;

- professional competencies to train specialists with a specialization in "economic security";

- professional requirements for the training of specialists in this area, formed on the basis of Russian science school, to ensure the economic security of business entities;

- innovative nature, which must be implemented in the educational process as a result of research work of teachers to improve the quality of education and make the learning process a practice-oriented;

- teaching materials that provide the use of active and interactive forms of development of educational process in this area;

- independent studentsresearch, built on a scientific approach, data statistics, including electronic databases produced in cooperation with employers in the educational process;

- development of modern scientific schools of economic security.

\section{CONCLUSIONS AND RECOMMENDATIONS}

Issues in hand correspond to the requirements and demands of the unstable time for Russian economy as the risks and threats of doing business in the market conditions fully manifest in the activities of economic entities, especially small businesses. Therefore, training of specialists in the sphere of economic security is relevant to the Russian economy.

It is also necessary to note the importance of the use and improvement of the methods of the educational process and educational technologies, including applicable forms of learning (e-learning, distance learning technologies) that will enhance the learning motivation of students in the field of professional training of future specialists to ensure the economic security.

Thus, the choice of the "economic security" profession is directly related to the following tasks:
- the involvement of employers, both for educational programs under preparation and in the process of theoretical training and practice;

- business integration with the scientific schools of higher education institutions;

- the development of specialized methodical support;

- a special edition of educational and scientific literature;

- preparation of teachers to work with students in this direction.

Partnership of educational institutions with real business serves as the foundation for innovation in preparing students to create the basis to improve the effectiveness of educational and scientific processes and, as a consequence, to improve the quality of training through the formation of students' competencies demanded in practice.

\section{REFERENCES}

[1] T.V. Alshansky "Protection technology against threats of economic and information security [Text] / T.V.Alshansky, Y.D.Kazhaeva, A.V.Mironenko // Collection of articles “NovaInfo” №28 - 2014 - pp 281-284.

[2] N.V. Beketov "The problems of economic security of the state in the sphere of foreign trade activities" // National interests: priorities and security. - 2009. - 124 p.

[3] A.O. Varyuha, L.V. Surzhenko "Modern threats to economic security of Russia" // Young scientist. - 2016. - №8.8. - P. 3-5.

[4] G.K. Zlotnikova, E.Y. Chehlan "Risk management in the automotive industry in Russia" // Modern problems of science and education. 2015. - №1.

[5] S. Lykshin"Development of the Russian economy and its restructuring as a guarantee of economic security" / S. Lykshin, A. Swinarenko // Questions of economy. - 2012. - №12.

[6] Federal Law № 390-FZ of 28.12.2010 (ed. From 10.05.2015) "On security".

[7] Electronic journal "Basic research" №9 - 2012. [electronic resource]. Access mode: http://www.rae.ru/fs/?section=content\&op=show_article\&article_id= 9999423, open access. 